\title{
Involvement of a cinnamyl alcohol dehydrogenase of Quercus suber in the defence response to infection by Phytophthora cinnamomi
}

\author{
A.C. Coelho ${ }^{\mathrm{a}, \mathrm{b}}$, M. Horta ${ }^{\mathrm{a}}$, D. Neves ${ }^{\mathrm{c}}$, A. Cravador ${ }^{\mathrm{a}, *}$ \\ ${ }^{a}$ Universidade do Algarve, Faculdade de Engenharia dos Recursos Naturais, Campus de Gambelas, 8005-139 FARO, Portugal \\ ${ }^{\mathrm{b}}$ Universidade do Algarve, Escola Superior de Educação, Campus da Penha, 8005-139 FARO, Portugal \\ ${ }^{\mathrm{c}}$ Universidade do Algarve, Instituto Transfronteiriço Universitário para a Ciência, a Cultura e o Ambiente, Campus de Gambelas, 8005-139 FARO, Portugal
}

Accepted 9 January 2007

\begin{abstract}
A gene encoding a potential NADPH-dependent cinnamyl alcohol dehydrogenase (QsCAD1) (GenBank accession no: AY362455) was identified in Quercus suber (cork oak). Its complete cDNA sequence was obtained by RACE-PCR, starting from total RNA extracted from roots of seedlings of $Q$. suber, infected with Phytophthora cinnamomi, the causal agent of the decline and sudden death of $Q$. suber and Quercus ilex subsp. rotundifolia in the Iberian Peninsula. Sequence information to perform the RACE-PCR was acquired from a polymorphic fragment (C9), specifically identified by cDNA-AFLP, in leaves of epicormic shoots of a cork oak tree that suffered sudden death. RT-PCR and hybridization analysis showed that the $Q s C A D 1$ gene is up-regulated in root seedlings of $Q$. suber infected with $P$. cinnamomi. QsCAD1 has a high structural homology with VR-ERE (Vigna radiata), an enzyme that detoxifies eutypine (produced by Eutypa lata, the causal agent of eutypa dieback of grapevines), to eutypinol, and with QrCAD1 (Q. ilex subsp. rotundifolia), EgCAD1 (Eucalyptus gunnii), MdCAD1 (Malus x domestica). Taken together, these results suggest that these enzymes, and namely QsCAD1 belong to a new group of CAD potentially involved in deactivation of toxins produced by phytopathogens.
\end{abstract}

(C) 2007 Elsevier Ltd. All rights reserved.

Keywords: Oak tree; Phytophthora cinnamomi; Cinnamyl alcohol dehydrogenase; Defence response

\section{Introduction}

The involvement of Phytophthora cinnamomi in the decline disease of cork oak (Quercus suber) and holm oak (Quercus ilex subsp. rotundifolia) in the Iberian Peninsula was hypothesized 10 years ago [1,2]. Recent extensive field surveys and greenhouse experiments provided evidence that $P$. cinnamomi infects the roots of these evergreen oaks. The reduction of the amount of roots available for water and nutrient uptake, caused by Phytophthora root rot, leads to widespread deaths of cork oak and holm oak, either directly, or by predisposing the trees to other biotic and abiotic stresses, factors usually nondeleterious to healthy plants $[1,3,4]$. In affected areas, some cork oaks exhibit a range of symptoms and a variable rate

\footnotetext{
*Corresponding author. Tel.: + 351289800935 ; fax: + 351289818419.

E-mail address: acravad@ualg.pt (A. Cravador).
}

of disease expression, while others die suddenly. Those that show evidence of chronic disease show a gradual deterioration of the crown that starts with leaf chlorosis and dieback of leaf bearing branches. As disease progresses, anomalous leaf fall occurs. New leaves, formed on apparently dead shoots, have reduced size, resulting in thinning of the crown and reduction of leaf area. Some affected trees show stem fluxes indicative of root malfunction. Trees showing such symptoms may survive for several years, depending on their resistance to disease progression and adaptation to environmental conditions. In contrast to chronic disease decline, the sudden death process is characterized by a quick drying of the leaves and death of the tree, within few months. The causes of these contrasting behaviours, slow decline and sudden death, are not known. Until now, no efficient methods have been found that will limit the threat of the disease to the oak ecosystem. 
Toxins produced by some fungi and bacteria play an important role in the expression of disease in plants. Toxin tolerance or resistance has been often associated with the capacity of the plant to metabolically detoxify the toxin [5-7]. As association between toxin tolerance and resistance to the disease has been frequently described [8,9], it is important to explain the mechanism underlying detoxification, and characterize the enzymes involved in this process.

A novel NADPH-dependent aldehyde reductase gene (VR-ERE) from Vigna radiata, that confers resistance to the grapevine fungal toxin eutypine [4-hydroxy-3(3-methyl-3-butene-1-ynyl) benzyl aldehyde], was recently described [10]. Eutypine is produced by the mycelium of Eutypa lata, the causal agent of eutypa dieback of grapevines [11-14]. It induces a number of symptoms, including dwarfed and withered shoots, marginal necrosis of the leaves, desiccation of the inflorescences and death of branches. It was suggested [15] that eutypine is transported from the trunk through the sap to the herbaceous parts of the vine, where it exerts its toxic action. The recombinant form of VR-ERE was shown to have a high affinity for 3substituted benzaldehydes, reducing them to alcohols. Its reducing activity was namely confirmed with eutypine, that it converts into the nontoxic corresponding benzyl alcohol, eutypinol [16]. The tolerance of some cultivars to this disease was correlated with their capacity to achieve this conversion.

The aim of the present work is to disclose cork oak genes involved in the defence response to infection by $P$. cinnamomi, namely in connection with the sudden death disease expression. As a first step in attempting this objective, we looked for polymorphic fragments present in mRNA profiles of leaves from adult asymptomatic trees and from trees that either exhibited symptoms of slow decline or underwent sudden death. In a second step, we have looked for the corresponding genes in roots of cork oak seedlings. The outcome of this approach was the identification of four genes, namely one that encodes a cinnamyl alcohol dehydrogenase (CAD), highly homologous to $V R-E R E$. The expression of CAD was analysed in infected and noninfected roots of $Q$. suber seedlings. The potential involvement of the uncovered CAD in the detoxification of a putative toxin produced by $P$. cinnamomi is discussed.

\section{Material and methods}

\section{1. $c D N A-A F L P$ analysis}

\subsubsection{Plant material}

Fully expanded young leaves were collected in May, from five adult cork oak trees (BS222A-4, BS250HL-0, BS110HL3, AS17BV-0 and AS21BV-3) located in infested sites from decline areas of Alentejo and Algarve regions of Portugal, and immediately stored at $-80^{\circ} \mathrm{C}$. P. cinnamomi had previously been isolated from roots and associated soil of oak trees located in those sites [3]. Trees were selected on the basis of the defoliation degree (DG), ranging from 0 (healthy tree) to 4 (dead tree), according to the scale proposed by Cadahia et al. [17]. The last figure, included in the designation of the trees, corresponds to the DG attributed at the moment of the collection of the leaves. Leaves from a cork oak tree affected by sudden death (BS222A-4) were collected from epicormic shoots present in the trunk.

\subsubsection{Extraction and purification of total RNA}

Total RNA was extracted from $50 \mathrm{mg}$ of leaves with the RNeasy Kit from Qiagen, according to the instructions supplied by the manufacturer [18]. Total RNA was then

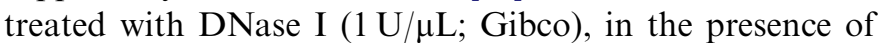
$2 \mu \mathrm{L}$ of RNaseout (40 U/ $\mu \mathrm{L}$; Gibco) [19]. The reaction occurred in a final volume of $100 \mu \mathrm{L}$, for $30 \mathrm{~min}$ at $37^{\circ} \mathrm{C}$. After DNA digestion, the total RNA was purified with the RNeasy Kit. The quality and the quantity of total RNA present in the samples were evaluated by UV spectrophotometry and by electrophoresis in denaturing agarose gel.

\subsection{3. cDNA synthesis}

The synthesis of cDNA was accomplished with the cDNA synthesis system (Roche), with modifications to the original protocol. Synthesis of the first cDNA strand was initiated with the degenerate primer [5'AGTGAATT $\mathrm{CT} 12 \mathrm{~V}(\mathrm{~V}=\mathrm{A} ; \mathrm{C} ; \mathrm{G}]$, comprised of an equimolar mixture of the three oligonucleotides [20]. Synthesis of the second cDNA strand and digestion of residual RNA were performed according to the kit protocol [21,22]. The double strand cDNA was then purified with the Qiaquick PCR purification kit (Qiagen). This methodology is designed to purify double-stranded DNA fragments from enzymatic reaction mixtures. Fragments ranging from $100 \mathrm{bp}$ to $10 \mathrm{~kb}$ were separated from polymerases, RNases, ligases, nucleotides and salts. In the process DNA binds to the QIAquick column (silica-gel membrane), and proteins or compounds resulting from the enzymatic reactions are eliminated by washing the column with buffers. In the last step of the protocol, the DNA is eluted from the column with $50 \mu \mathrm{L}$ of the elution buffer $(10 \mathrm{mM}$ Tris- $\mathrm{Cl}, \mathrm{pH} 8.5)$. The volume of cDNA samples, eluted from the column, was reduced to a final volume of $20 \mu \mathrm{L}$ by centrifugation under vacuum. cDNA samples $(20 \mu \mathrm{L})$ were then subjected to the standard AFLP template production [23]. The cDNA was first digested with $E c o$ RI and $M s e I(2.5 \mathrm{U} / \mu \mathrm{L}$ each) in a restriction buffer $(50 \mathrm{mM}$ Tris $-\mathrm{HCl} \mathrm{pH}-7.5$, $50 \mathrm{mM}$ magnesium acetate, $250 \mathrm{mM}$ potassium acetate), in a total volume of $25 \mu \mathrm{L}$ for $2 \mathrm{~h}$ at $37^{\circ} \mathrm{C}$ (AFLP Core Reagent Kit, GIBCO BRL). After enzyme inactivation at $70^{\circ} \mathrm{C}$ for $15 \mathrm{~min}, E c o$ RI $(5 \mathrm{pmol})$ and $M s e I$ (50 pmol) adaptors were ligated to cDNA digested fragments. The reaction was performed for $2 \mathrm{~h}$ at $37^{\circ} \mathrm{C}$ in ligase buffer, $1 \mathrm{U}$ of T4 DNA ligase and ATP $(0.4 \mathrm{mM})$ (AFLP Core Reagent Kit, GIBCO BRL). The cDNA ligated to the adaptor was pre-amplified using the following cycling parameters: 28 cycles of $30 \mathrm{~s}$ at $94^{\circ} \mathrm{C} ; 60 \mathrm{~s}$ at $56^{\circ} \mathrm{C}$ and $60 \mathrm{~s}$ 
at $72^{\circ} \mathrm{C}$. The pre-amplification reaction was carried out with $15 \mathrm{pmol}$ of primer EcoRI $+0,15 \mathrm{pmol}$ of primer $M s e \mathrm{I}+0.5 \mu \mathrm{L}$ of cDNA template, $0.2 \mu \mathrm{L}$ of Taq DNA polymerase in an appropriate Taq buffer. Aliquots of the pre-amplification reaction were run on a $1.5 \%$ agarose gel, to verify the presence of a smear of cDNA, before proceeding. The pre-amplified cDNA was diluted in water, in a ratio of 1:10 and was used as a template for the selective amplification which involved the use of 20 primers pairs with $3^{\prime}$ extensions of one, two or three bases. Primer EcoRI was end-radiolabelled ( $\gamma^{33} \mathrm{P}$ dATP; Redivue, Amersham Pharmacia) with standard protocols $[24,25]$. The following cycling parameters were applied: 13 cycles with denaturation of $30 \mathrm{~s}$ at $94^{\circ} \mathrm{C}$, primer annealing of $30 \mathrm{~s}$ at $65^{\circ} \mathrm{C}$. The annealing temperature was lowered by $0.7^{\circ} \mathrm{C} /$ cycle during the first 12 cycles, until reaching $56^{\circ} \mathrm{C}$. Polymerization of 60 s at $72^{\circ} \mathrm{C}$, and then 18 cycles of $30 \mathrm{~s}$ at $94^{\circ} \mathrm{C}, 30$ s at $56^{\circ} \mathrm{C}$ and $60 \mathrm{~s}$ at $72^{\circ} \mathrm{C}$. Labelled selective amplification products were separated on standard $6 \%$ polyacrylamide sequencing gels. After electrophoresis, the gel was dried on filter paper (3MM paper; Whatmann) and exposed to X-ray film for $30 \mathrm{~h}$. The cDNA fragments were visualised by autoradiography, after positional marking the gel and the film.

\subsection{Isolation and sequencing of fragments}

Polymorphic gene fragments, present only in the mRNA profile of cork oak tree affected by sudden death, were excised from the gel. A piece of the dried gel, containing the band of interest, was cut out and soaked in $40 \mu \mathrm{L}$ of $\mathrm{H}_{2} \mathrm{O}$ for $10 \mathrm{~min}$ on ice. The sample was then heated for $15 \mathrm{~min}$ at $95^{\circ} \mathrm{C}$ and cooled again on ice. After a brief centrifugation ( $30 \mathrm{~s} ; 13,000 \mathrm{rpm}), 5 \mu \mathrm{L}$ of the supernatant were transferred to another tube. Re-amplification of the recovered fragment was performed under the same conditions, and with the same primer combination used in the reaction which generated the product of interest. The re-amplified PCR product was run on a $2 \%$ agarose gel, cut out and purified with the Qiaquick PCR Purification Kit (Qiagen) and finally cloned into the pCRII Topo vector, with the TA Cloning Kit (Invitrogen). Manufacturer's instructions for these kits were followed throughout. The fragments were sequenced with an Applied Biosystems PRISM Ready Reaction DyeDeoxy Terminator cycle sequencing kit and an automated sequencer.

\subsection{Rapid amplification of $5^{\prime}$ and $3^{\prime}$ complementary $c D N A$ ends (RACE-PCR)}

\subsubsection{Plant material}

Seeds of cork oak and holm oak were germinated at room temperature $\left(25^{\circ} \mathrm{C}\right)$ in a mixture of vermiculite and sand. When the main root reached $8-10 \mathrm{~cm}$, the seedlings were separated from the sand, washed with water and transferred to Petri dishes to be infected with P. cinnamomi. Roots still attached to the seeds, were inoculated with slices of agar containing P. cinnamomi (isolate PA20) mycelium grown for 1 week in V8 solid medium [26]. Roots in contact with slices of mycelium were covered with aluminium foil, and placed at $25^{\circ} \mathrm{C}$ for $24 \mathrm{~h}$. The infected roots were then cut and stored at $-80^{\circ} \mathrm{C}$.

\subsubsection{Extraction and purification of total RNA}

Total RNA was extracted from $50 \mathrm{mg}$ of roots of cork oak seedlings with RNeasy Kit from Qiagen, according to the instructions supplied by the manufacturer [18]. DNase treatment of total RNA was performed as described above (cDNA-AFLP analysis).

\subsubsection{RACE-PCR}

RACE-PCR $\left(3^{\prime} / 5^{\prime}\right)$ was performed to obtain full length cDNA of the gene comprising the C9 cDNA-AFLP fragment. Three and five prime ends were obtained with a GeneRacer Kit (Invitrogen) following the manufacturer's instructions $[27,28]$.

DNase treated total RNA $(1 \mu \mathrm{g})$ extracted from roots of cork oak seedlings, infected with P. cinnamomi, was used as template in the following steps:

(1) $5^{\prime}$ phosphates were removed from truncated mRNA and from non mRNA with calf intestinal phosphatase (CIP). The reaction was performed for $1 \mathrm{~h}$ at $50{ }^{\circ} \mathrm{C}$, in a total volume of $15 \mu \mathrm{L}$, comprised of $1 \mu \mathrm{L}$ CIP $(10 \mathrm{U} / \mu \mathrm{L}), 1 \mu \mathrm{g}$ of total RNA, $1 \mu \mathrm{L}$ of RNase inhibitor $(10 \mathrm{U} / \mu \mathrm{L}), 1 \mu \mathrm{L}$ of CIP buffer $(0.5 \mathrm{M}$ Tris- $\mathrm{HCl}, \mathrm{pH} 8.5$; $1 \mathrm{mM}$ EDTA). RNA was precipitated and washed with ethanol and resuspended in $7 \mu \mathrm{L}$ DEPC water as described in the instruction manual of GeneRacer ${ }^{\mathrm{TM}}$ Kit (Invitrogene).

(2) Dephosphorylated RNA $(6 \mu \mathrm{L})$ was treated with tobacco acid pyrophosphatase (TAP) to remove $5^{\prime}$ cap structure from intact, full-length RNA. The reaction was carried out for $1 \mathrm{~h}$ at $37^{\circ} \mathrm{C}$ in a total volume of $10 \mu \mathrm{L}$, comprised of $1 \mu \mathrm{L}$ of TAP $(0.5 \mathrm{U} / \mu \mathrm{L})$, $1 \mu \mathrm{L}$ of TAP buffer $(0.5 \mathrm{M}$ sodium acetate, $\mathrm{pH} 6$; $10 \mathrm{mM}$ EDTA; $1 \% \beta$-mercaptoethanol; $0.1 \%$ TritonX$100), 1 \mu \mathrm{L}$ of RNase inhibitor $(10 \mathrm{U} / \mu \mathrm{L})$. RNA was precipitated and washed with ethanol and resuspended in $6 \mu \mathrm{L}$ DEPC water, as described in the instruction manual of GeneRacer ${ }^{\mathrm{TM}}$ Kit (Invitrogene).

(3) For selective ligation of an RNA oligonucleotide (RNA Oligo) to the $5^{\prime}$ ends of decapped mRNAs $6 \mu \mathrm{L}$ of dephosphorylated decapped RNA were added to $0.25 \mu \mathrm{g}$ of lyophilized RNA Oligo (5'CGACUGGA GCACGAGGACACUGACAUGGACUGAAGGAG UAGAAA $3^{\prime}$ ), the mixture was incubated for $5 \mathrm{~min}$ at $65^{\circ} \mathrm{C}$ and chilled on ice for $2 \mathrm{~min}$. After a brief centrifugation $(5 \mathrm{~s}, 13,000 \mathrm{rpm}), 1 \mu \mathrm{L}$ of RNase Inhibitor $(10 \mathrm{U} / \mu \mathrm{L}), 1 \mu \mathrm{L}$ of ligase buffer $(330 \mathrm{mM}$ Trisacetate, $\mathrm{pH} 7.8 ; 660 \mathrm{mM}$ potassium acetate; $100 \mathrm{mM}$ magnesium acetate; $5 \mathrm{mM}$ DTT), $1 \mu \mathrm{L}$ ATP $(10 \mathrm{mM})$, $1 \mu \mathrm{L}$ of $\mathrm{T} 4$ RNA ligase $(5 \mathrm{U} / \mu \mathrm{L})$ were added. The reaction mixture was incubated for $1 \mathrm{~h}$ at $37^{\circ} \mathrm{C}$. RNA was precipitated and washed with ethanol and 
resuspended in $13 \mu \mathrm{L}$ DEPC water, as described in the instruction manual of GeneRacer ${ }^{\mathrm{TM}}$ Kit (Invitrogene).

(4) The synthesis of cDNA was primed by an oligonucleotide composed of 18 thymidine and 36 additional nucleotides (5'GCTGTCAACGATACGCTACGTAACGGCATGACAGTGT $_{18} 3^{\prime}$ ) (oligo-dT). Superscript ${ }^{\mathrm{TM}}$ II RNase $\mathrm{H}^{-}$(GIBCO) was used as reverse transcriptase. One microlitre of oligo-dT $(37.5 \mu \mathrm{M}), 2 \mu \mathrm{L}$ dNTPs $(10 \mathrm{mM})$ and water were added to total RNA, to a final volume of $31 \mu \mathrm{L}$. The reaction mixture was incubated at $65^{\circ} \mathrm{C}$ for $5 \mathrm{~min}$ and then chilled on ice for $2 \mathrm{~min}$. Then, $4 \mu \mathrm{L}$ of First Strand Buffer $(250 \mathrm{mM}$ Tris- $\mathrm{HCl}, \mathrm{pH} 8.3 ; 375 \mathrm{mM} \mathrm{KCl} ; 15 \mathrm{mM} \mathrm{MgCl} 2), 2 \mu \mathrm{L}$ $0.1 \mathrm{M}$ of DTT, $1 \mu \mathrm{L}$ RNaseOUT $(40 \mathrm{U} / \mu \mathrm{l}), 2 \mu \mathrm{L}$ of Superscript $(200 \mathrm{U} / \mu \mathrm{L})$ were added to the reaction mixture that was further incubated at $42{ }^{\circ} \mathrm{C}$ for $1 \mathrm{~h}$. The enzyme was inactivated at $70{ }^{\circ} \mathrm{C}$ for $15 \mathrm{~min}$, then $1 \mu \mathrm{L}(2 \mathrm{U})$ of RNase $\mathrm{H}$ was added and the reaction was performed at $37^{\circ} \mathrm{C}$ for $20 \mathrm{~min}$.

The obtained single strand cDNA was used as template for the amplification of $3^{\prime}$ and $5^{\prime}$ ends.

Amplification of the $3^{\prime}$ end was carried out with GeneRacer $3^{\prime}$ primer (5'GCTGTCAACGATACGCTACG TAACG3') that anneals with oligo-dT and with a primer, specific to the gene comprising the C9 fragment (C9SP4; 5'CAAAGCAAATCTACTGGAAG3'). Amplification was performed in a total volume of $50 \mu \mathrm{L}$, comprised of $5 \mu \mathrm{l}$ of PCR buffer (200 mM Tris- $\mathrm{HCl}$, pH 7.5, $1 \mathrm{M} \mathrm{KCl} ; 15 \mathrm{mM}$ $\mathrm{MgCl}_{2}, 10 \mathrm{mM}$ DTT, $1 \mathrm{mM}$ EDTA, $1 \% \mathrm{v} / \mathrm{v}$ Tween $20,1 \%$ $\mathrm{v} / \mathrm{v}$ Nonidet P40), $5 \mu \mathrm{L}$ dNTPs $(2 \mathrm{mM}$ each $), 2 \mu \mathrm{L}$ of primers $(10 \mathrm{mM}), 1 \mu \mathrm{L}$ of cDNA solution, $0.75 \mu \mathrm{L}$ of Expand High Fidelity Polymerase $(3.5 \mathrm{U} / \mu \mathrm{L})$. The following cycling parameters were applied: 2 min at $95^{\circ} \mathrm{C} ; 30$ cycles with denaturation at $95^{\circ} \mathrm{C}$ for $30 \mathrm{~s}$, primer annealing at $50{ }^{\circ} \mathrm{C}$ for $30 \mathrm{~s}$, polymerisation at $72^{\circ} \mathrm{C}$ for $60 \mathrm{~s}$; one cycle at $72^{\circ} \mathrm{C}$ for $7 \mathrm{~min}$.

Amplification of the $5^{\prime}$ end was carried out with GeneRacer $5^{\prime}$ primer (5'CGACTGGAGCACGAGGACA CTGA3') that anneals with the DNA complementary to RNA Oligo and with a primer, specific to the gene comprising the $\mathrm{C} 9$ fragment (C9SP2; 5'TCACAGCCCTC AACAGCAGA3'). Amplifications conditions were identical to those above described for the $3^{\prime}$ end amplification.

The products of the amplification reactions were cloned into the pCRII Topo vector, with the TA Cloning Kit (Invitrogen), and sequenced.

\subsection{Qualitative analysis by RT-PCR and hybridization}

\subsubsection{Plant material}

Seeds of cork oak and holm oak were germinated at room temperature $\left(25^{\circ} \mathrm{C}\right)$ in a mixture of vermiculite and sand. When the main root reached $8-10 \mathrm{~cm}$, the seedlings were separated from the sand and washed with water. Some roots were cut and stored at $-80^{\circ} \mathrm{C}$ and others were transferred to Petri dishes, to be infected with
P. cinnamomi. The infection of the root seedlings was performed as described above.

\subsubsection{RT-PCR and hybridization}

Total RNA $(2 \mu \mathrm{g})$ was extracted from noninfected roots of cork oak seedlings, and from roots that were put in contact with $P$. cinnamomi mycelium for $24 \mathrm{~h}$. cDNA was synthesized with Superscript II RNase H-reverse transcriptase, in a total volume of $40 \mu \mathrm{L}$. Two microliters of the cDNA synthesis solution were diluted 50, 100 and 200 times, and $10 \mu \mathrm{L}$ of these dilutions were used as cDNA template for amplification reactions. Fragments greater than 1000 bp from $Q s C A D 1$ transcripts were amplified with a specific primer, C9SP4 for the known sequence and an oligo-dT primer. The following primers were used for the amplification of the actin fragment: 5'GCCGGTGACG ACGCCCCGCG3' and 5'CCACGCTCCGTCAGGTACT TC $3^{\prime}$. PCR products were separated on $1 \%$ agarose gels and blotted to membrane (Hybond-N+) on a Trans-Blot SD semi-dry electrophoretic transfer cell. The specificity of the amplified products was confirmed by hybridization. A DNA fragment (75 bp) from $Q s C A D 1$ gene, obtained by amplification with C9SP2 and C9SP4 primers, labelled with digoxigenin, was used as probe. Hybridization of digoxigenin-labelled probes, with the target DNA, was achieved at $42^{\circ} \mathrm{C}$ in the presence of DIG Easy Hybridization buffer (Roche). Digoxigenin-labelled nucleic acid hybrids were detected with a Dig Luminescent Detection Kit (Roche).

\subsection{Phylogenetic analysis}

The amino acid sequences of CAD 1 and 2, identified in $Q$. suber, were aligned with those of their homologues in plants by the CLUSTAL W algorithm [29]. Phylogenetic analysis was conducted with the neighbour-joining method [30].

\subsection{Sequence analysis}

The cDNA sequences from RACE-PCR and cDNAAFLP analysis were aligned and compared through the National Centre for Biotechnology Information (NCBI) GenBank (http://www.ncbi.nlm.nih.gov/BLAST/) with the basic local alignment search tool (BLAST) algorithm [31], the fast A programme from the GCG software (Genetics Computer Group, University of Wisconsin, Madison, 1981) and the Vector NTI 6 software $^{\mathrm{TM}}$ (InforMax. Inc).

\section{Results}

\subsection{Identification of a gene from $Q$. suber encoding a potential cinnamyl alcohol dehydrogenase}

cDNA-AFLP methodology was used to identify polymorphisms in genes that are expressed in leaves of cork oak trees presenting symptoms of the decline disease, manifested as slow decline or sudden death [36]. The severity of 
the disease was evaluated according to different DGs based on the scale proposed by Cadahia et al. [17]. The pattern of mRNAs extracted from young leaves of cork oak trees exhibiting various DGs, and growing in $P$. cinnamomi infested soil, showed a high polymorphism. Twenty-seven out of 122 up-regulated cDNA-AFLP fragments were cloned and sequenced (not shown). One was shown to have a high homology with $C A D 1$ gene sequence and used to characterize this gene in $Q$. suber as described below. The mRNA was extracted from young leaves of five cork oak trees: BS222A-4, BS250HL-0, BS110HL-3, AS17BV-0 and AS21BV-3, with DGs of $4,0,3,0$ and 3, respectively, located in decline areas where $P$. cinnamomi had already been isolated with success from roots and associated soils.

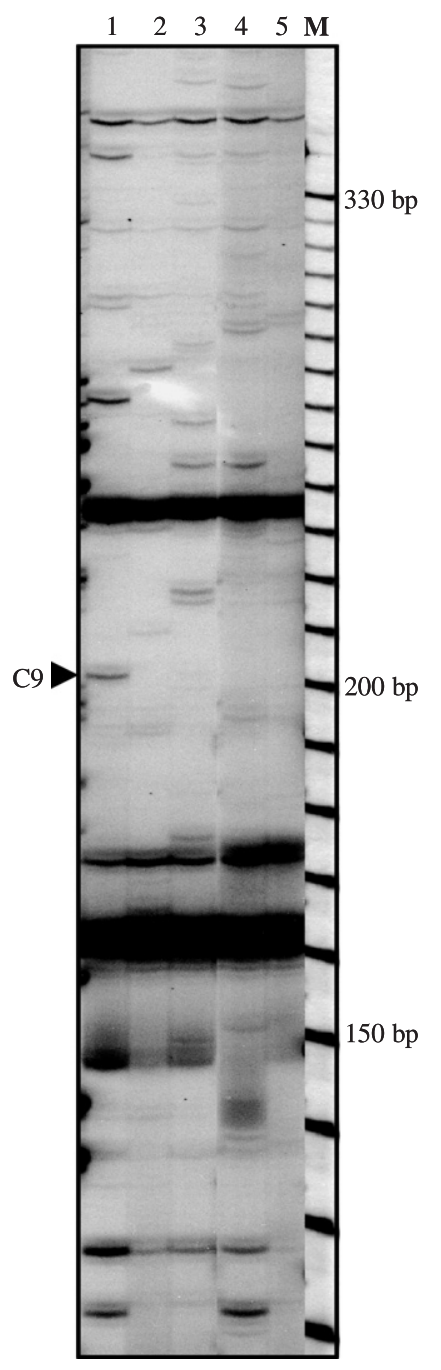

Fig. 1. Autoradiogram electrophoretic separation of cDNA-AFLP fragments produced with the primer combination EcoRI-ACC/MseIACC. RNA was isolated from young leaves collected from five adult trees (BS222A-4; BS250HL-0; BS110HL-3; AS17BV-0 and AS21BV-3) located in infested sites from decline areas of Alentejo and Algarve regions of Portugal. Lanes 1-5: cDNA-AFLP patterns of cork oak trees: healthy trees (lanes 2 and 4); trees affected by sudden death (lane 1) or by slow decline (lanes 3 and 5). M: DNA molecular marker. The $200 \mathrm{bp}$ gene fragment C9 (arrow) produced specifically in reactions containing cDNA from BS222A-4 tree is indicated.
In the mRNA profile obtained with primer combination I2 (EcoRI-ACC; MseI-ACC), a polymorphic fragment with $200 \mathrm{bp}$ (named C9) was identified. This fragment was exclusively present in the cork oak tree BS222A-4 that was affected by sudden death (Fig. 1). The mRNA, used for the cDNA-AFLP analysis, was extracted from leaves of epicormic shoots present in the trunk. The comparison of C9 fragment nucleotide sequence with GenBank data, showed similarities of $85 \%$ and $77 \%$ with sequences of genes that code for CADs identified in Malus $x$ domestica ${ }^{1}$ and in Eucalyptus gunnii, ${ }^{2}$ respectively. The complete cDNA sequence of the gene corresponding to the C9 fragment was obtained by RACE-PCR, starting from total RNA extracted from roots of seedlings of $Q$. suber infected with $P$. cinnamomi. The amplification was performed with primers defined in regions of the $\mathrm{C} 9$ fragment that are conserved in respect to the above referred to CADs. The resulting cDNA was found to be $1399 \mathrm{bp}$ long. It is designated henceforth as $Q S C A D 1$. The open reading frame (978 bp) encoded a protein of 326 amino acids with a calculated molecular mass of $35922 \mathrm{Da}$, and a calculated isoelectric point of 7.72 . The $5^{\prime}$-UTR contained 54 nucleotides and the $3^{\prime}$-UTR contained 361 nucleotides (Fig. 2). Three putative polyadenylation signal sequences appeared at 33,181 and $313 \mathrm{nt}$ downstream of the TAA termination codon. $Q S C A D 1$ open reading frame codes for a protein that is $80.7 \%$ and $76.5 \%$ homologous to the CADs identified in $M . x$ domestica and E. gunnii, respectively. QsCAD1 and $\mathrm{C} 9$ sequences have almost complete homology until nucleotide 111 of C9. Downstream of this nucleotide, C9 and QSCADI sequences diverge significantly from each other (Fig. 3).

\subsection{Increased expression of $Q S C A D 1$ gene in roots of $Q$. suber infected with P. cinnamomi analysed by RT-PCR and hybridization}

To observe the expression pattern of $Q s C A D 1$, total RNA extracted from roots of $Q$. suber seedlings, either noninfected or infected with $P$. cinnamomi was analysed by RT-PCR and hybridization. The synthesis of complete cDNAs was primed with a $54 \mathrm{bp}$ oligonucleotide (GeneRacer ${ }^{\mathrm{TM}}$ Oligo dT Primer) containing a dT tail of 18 nucleotides and a priming site of known sequence for specific primers. In order to select specific QsCADI sequences, an amplification reaction was performed with serial dilutions of cDNA solution $(1: 50 ; 1: 100 ; 1: 200)$, and specific primers to the $Q S C A D 1$ and to the oligonucleotide used to prime the cDNA synthesis (vide Section 2). Simultaneously, control primers for the constitutively expressed gene actin were also used. These primers were designed in the more conserved regions of plant actin genes and amplified a $500 \mathrm{bp}$ fragment. The amplification products were separated on an agarose gel electrophoresis,

\footnotetext{
${ }^{1}$ GenBank accession no: AF053084.

${ }^{2}$ GenBank accession no: X88797.
} 


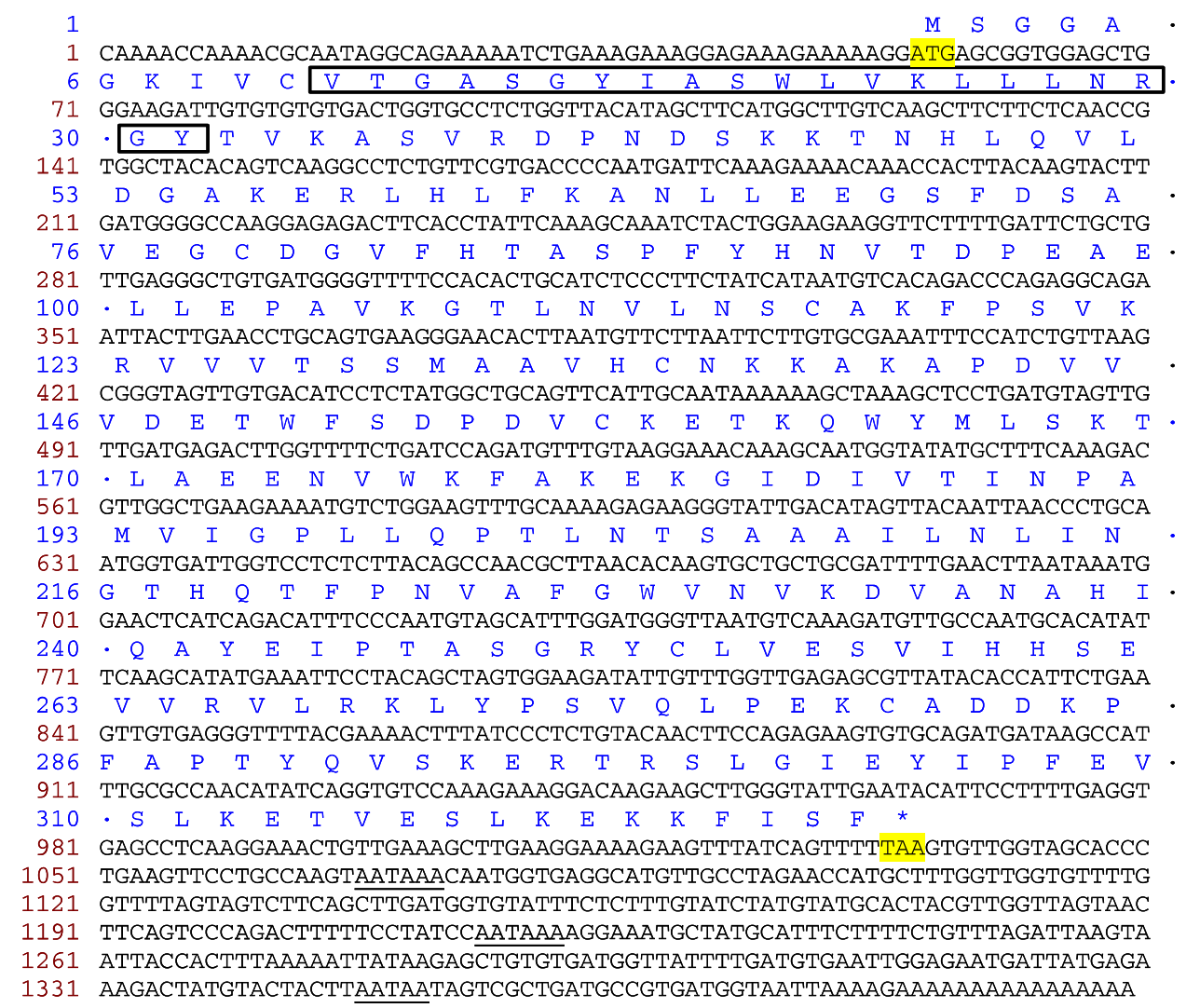

Fig. 2. Nucleic and deduced amino acid sequences of the CAD1 cDNA from Quercus suber. Initiation and termination codons are highlighted. Polyadenilation signal sequences (AATAAA and AATAA) are underlined. Boxed amino acids represent the putative NAD/NADP(H) binding domain located in the $\mathrm{N}$-terminal region of the protein.

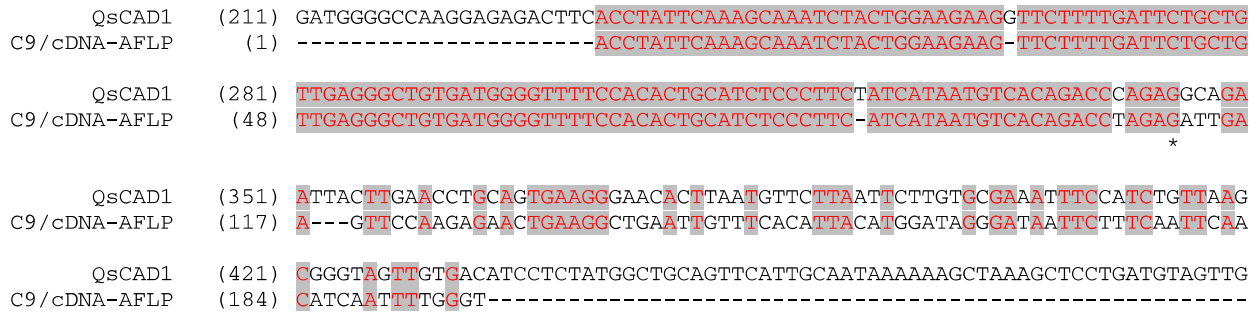

Fig. 3. Nucleic sequence alignment between $Q s C A D 1$ cDNA and C9 fragment. Considerable sequence divergence begins at nucleotide 111 of C9 fragment marked with *.

transferred to a Hybond- $\mathrm{N}^{+}$membrane and detected by hybridization with a digoxigenin labelled probe, specific and internal to the amplified fragment (Fig. 4). The intensity of the emitted hybridization signals was measured by densitometric scanning; the absorbance values were found to be directly correlated with the amount of QsCADI mRNA, accumulated either in noninfected roots of $Q$. suber seedlings or in roots infected by $P$. cinnamomi. Fig. 4 shows the expression of $Q S C A D 1$ gene in noninfected roots of $Q$. suber seedlings and in roots exposed $24 \mathrm{~h}$ to infection by $P$. cinnamomi. The intensity of the absorbance signal is higher in the infected roots for all the cDNA dilutions decreasing, as expected, with dilution increment, indicating that the expression of $Q S C A D 1$ increased in the first $24 \mathrm{~h}$ of the interaction between $Q$. suber and $P$. cinnamomi.
In fact, two cDNA fragments, slightly longer than $1000 \mathrm{pb}$, were detected by hybridization with the probe specific to $Q s C A D 1$. The two amplified cDNA fragments correspond probably to two different copies of the QsCADI gene or to two alleles of the same gene. However, the presence of three putative polyadenylation sites located in the $3^{\prime}$ UTR of the gene upstream from the poly(A) tail, and separated by 127 and 142 nucleotides, suggests that transcripts of different sizes are produced (Fig. 4). Similar results were obtained by Goffner et al. [32] in E. gunnii and in tobacco. The authors identified two genes in E. gunnii genome coding for CAD 1 that differed slightly in their coding regions, and isolated two distinct CAD1 cDNAs in tobacco.

The extremely high sensitivity of RT-PCR allows the detection of rare mRNAs, mRNAs in a small number of 


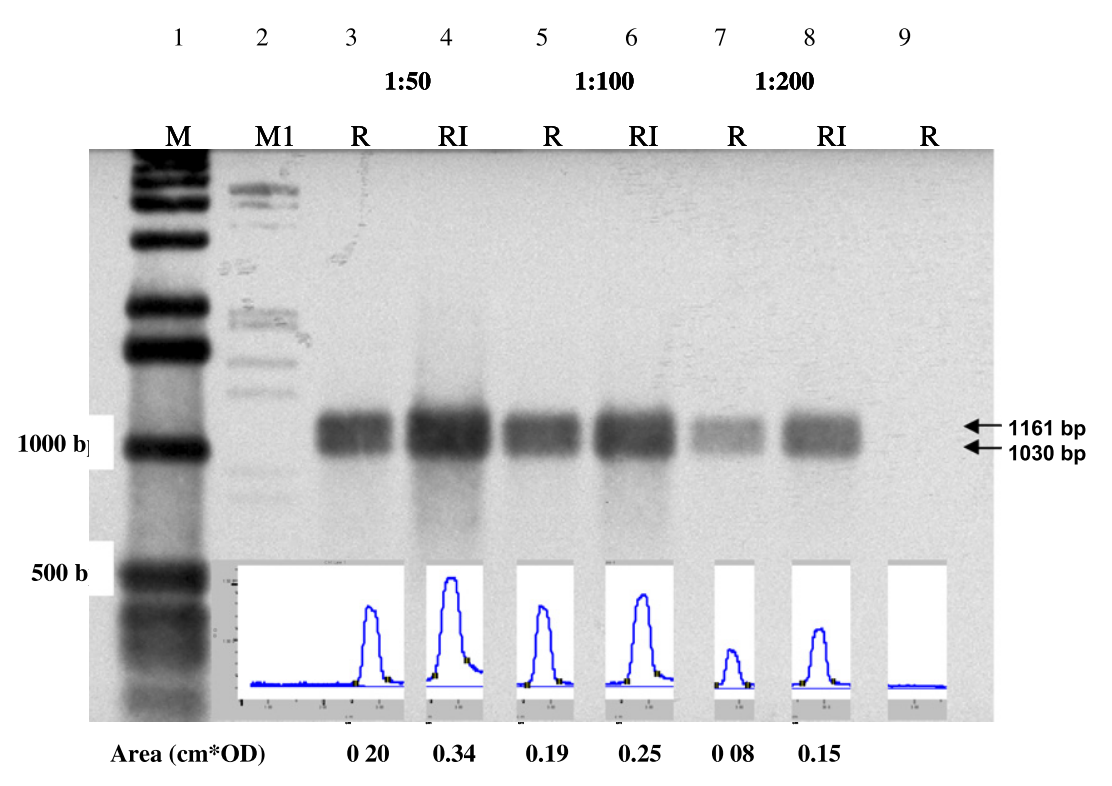

Fig. 4. Expression of $Q S C A D$ gene from $Q$. suber non-infected (R) and infected (RI) roots. The infection was performed by putting the roots in contact with $P$. cinnamomi mycelia for $24 \mathrm{~h}$. RT-PCR products from total RNA were separated by agarose gel electrophoresis, transferred to a Hybond $\mathrm{N}^{+}$ membrane, denaturated and hybridized with a digoxigenin labelled probe. The intensity of the hybridization signals was measured by densitometric scanning. Integration values of absorbance curve's areas are shown at the bottom. Lanes 1 and 2: molecular markers; lanes 3-8: cDNA synthesis solutions were diluted 50,100 and 200 times as indicated and $10 \mu \mathrm{L}$ of these dilutions were used as cDNA template for amplification reactions; lane 9: actin cDNA.

cells or in small amounts of tissue as well as mRNAs expressed in mixed-cell populations [33-35]. The method is adequate to study the expression of genes in roots of woody plants, because the amount of mRNA extracted is always very small, and usually insufficient for analysis by Northern blot. Furthermore, the analysis by RT-PCR and hybridization can be performed in highly diluted mRNA extracts, so that the concomitant dilution of acids and phenols present in necrotic roots prevents them from interfering with the enzymatic reactions. The specificity of the amplification reaction was tested by hybridization with a probe directed to the $Q S C A D I$ cDNA. Efficiency of PCR and absence of contamination were confirmed by analysis of actin gene expression (not shown).

The ability to amplify highly diluted cDNA confirms the effectiveness and sensitivity of the method.

\subsection{Phylogenetic analysis}

The amino acid sequence deduced from the QsCADI gene was compared with a partial sequence coding for another potential cinnamyl alcohol dehydrogenase (QsCAD2) identified in $Q$. suber 36 and with 34 CADs identified in other plant species present in the GenBank. To determine the phylogenetic relationship between them the amino acid sequences were aligned by the CLUSTAL W algorithm [29] and the phylogenetic analysis was conducted with the neighbour-joining method [30].

The phylogenetic tree shows that CAD sequences grouped in three distinct clusters $(\mathrm{A}-\mathrm{C})$ reflecting probably their biological similarities (Fig. 5). Cluster A included CADs isolated from E. gunnii (EgCAD2; [37], Lolium perenne (LpCAD3), [38] and Medicago sativa (MsaCAD2), [39] among others. These CAD homologues share more than $70 \%$ identity and are implicated in the synthesis of lignin and/or suberin that use specifically cinnamyl aldehydes ( $p$-coumaryl, coniferyl and sinapyl) as substrates. They catalyse the NADPH-dependent reduction of these aldehydes to the corresponding alcohols [40]. Eucalyptus CAD2 was classified as a zinc-containing longchain alcohol dehydrogenase, based on the presence of the consensus sequence GHEXXGXXXXXGXXV that includes a histidine residue known to be the second ligand of the catalytic zinc atom [37] and on the motif GXGXXG characteristic of the NADP-binding domain of CADs. The QsCAD2 partial sequence forms a subgroup with PoptCAD from Populus tremuloides [41].

The cluster B grouped CADs such as MsaCAD1 (M. sativa), [39] and PcELI3 (Petroselinum crispum), [42] whose expression is induced in response to wounding or by elicitor molecules secreted in plant-pathogen incompatible interactions. These enzymes accept a more diversified spectrum of substrates than CADs of group A such as cinnamyl, benzyl and aliphatic aldehydes, and use NADPH as co-substrate. The amino acid sequences of MsaCAD1 and PcELI3 have in common with their homologue CADs from cluster $\mathrm{A}$, the characteristic domains present in all alcohol dehydrogenases mentioned above.

Cluster $\mathrm{C}$ grouped proteins with sequence identity higher than $68 \%$ with VR-ERE, an NADPH-dependent reductase, involved in the deactivation of eutypine, 4-hydroxy-3(3-methyl-3-butene-1-ynyl) benzyl aldehyde, a toxin produced by $E$. lata, the causal agent of eutypa dieback of grapevines (Fig. 5). In particular, QsCAD1 is highly 


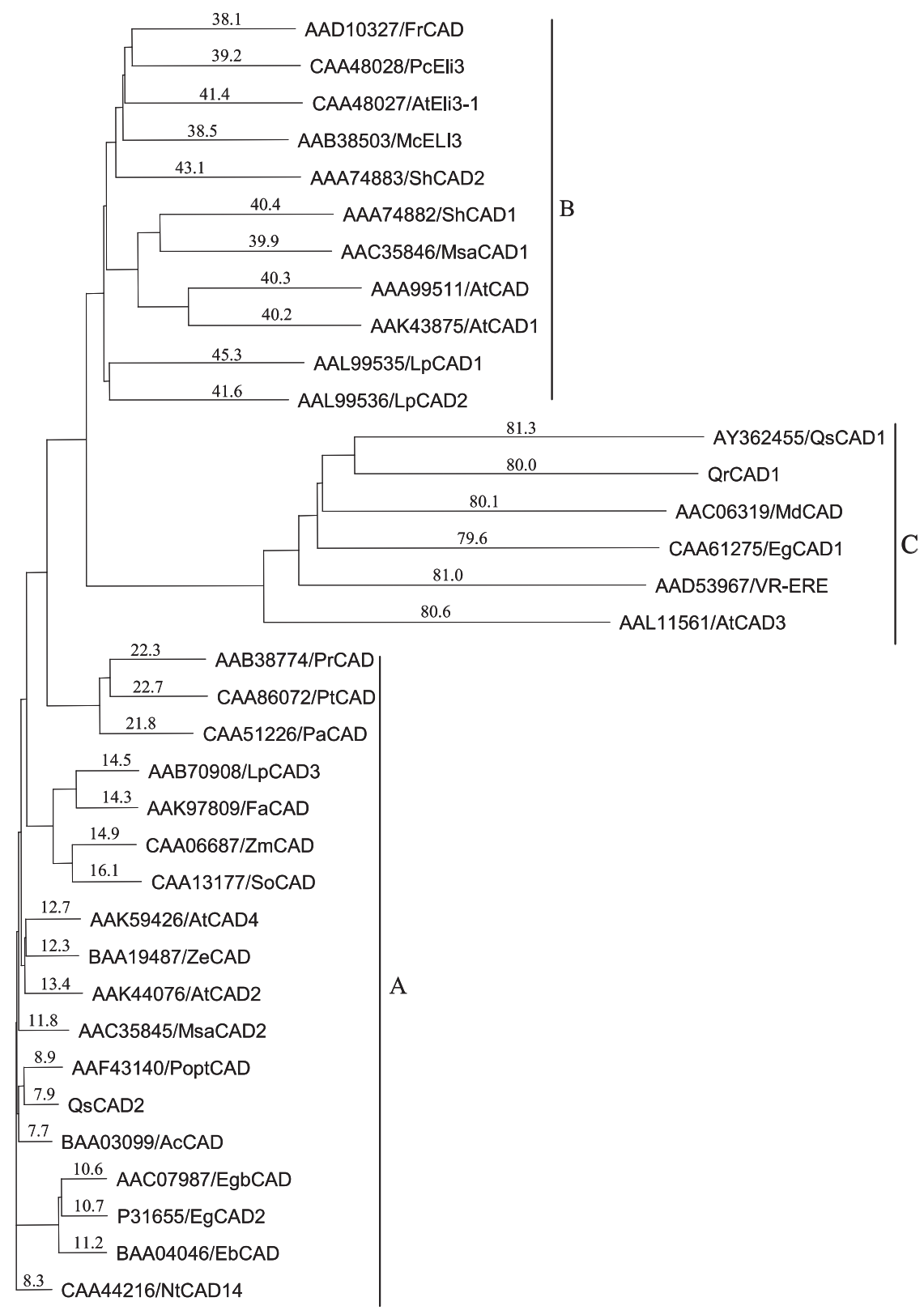

Fig. 5. Phylogenetic tree constructed from amino acid sequences of plant CADs including VR-ERE. The corresponding GenBank accession numbers are noted in the phylogenetic tree. CADs belong to the following plant species: Pinus radiata (PrCAD); Pinus taeda (PtCAD); Picea abies (PaCAD); Lolium perenne (LpCAD1, LpCAD2, LpCAD3); Festuca arundinacea (FaCAD); Zea mays (ZmCAD); Saccharum officinarum (SoCAD); Arabidopsis thaliana (AtCAD, AtCAD1, AtCAD2, AtCAD3, AtCAD4; AtEli3-1); Zinnia elegans (ZeCAD); Medicago sativa (MsaCAD1, MsaCAD2); Populus tremuloides (PoptCAD); Aralia cordata (AcCAD); Eucalyptus globulus (EgbCAD); Eucalyptus gunnii (EgCAD1, EgCAD2); Eucalyptus botryoides (EbCAD); Nicotiana tabacum (NtCAD14); Stylosanthes humilis (ShCAD1, ShCAD2); Mesembryanthemum crystallinum (McELI3); Fragaria x ananassa (FrCAD); Petroselinum crispum (PcEli3); Malus domestica (MdCAD); Quercus suber (QsCAD1; QsCAD2); Quercus ilex subsp. rotundifolia (QrCAD1); Vigna radiata (VR-ERE). Substrate range and motifs of coenzyme binding domains are features that differentiate clusters A-C and are explained in the text. Distances are proportional to evolutionary divergences expressed in substitution per 100 sites and are indicated on the tree branches.

homologous (>96\%) to QrCAD1 deduced from the cDNA of $Q$. ilex subsp. rotundifolia (our unpublished results) and to MdCAD1 $(>80 \%)$, the protein deduced from the MdCADl gene of Malus $x$ domestica.

EgCAD1 (E. gunnii), MdCAD1, QsCAD1, QrCAD1 have completely divergent primary sequences from CADs present in clusters $\mathrm{A}$ and $\mathrm{B}$, lacking all the conserved domains typical of alcohol dehydrogenases. Instead, the N- terminal part of proteins from cluster $\mathrm{C}$, is the most conserved among all these proteins and VR-ERE, and includes a block of 21 amino acids corresponding to the putative NAD/NADP $(H)$ binding site [43]. This motif is also found in proteins including cinnamoyl-CoA reductases (CCR) from Eucalyptus gunnii ${ }^{3}$ and dihydroflavonol

\footnotetext{
${ }^{3}$ GenBank accession nos.: CAA56103; CAA66063.
} 
reductases (DFR) from several plant species. ${ }^{4}$ It is also present in the protein encoded by the drought-inducible gene CPRD14 isolated from Vigna unguiculata [44] and in the NADPH-HC toxin reductase gene $H M I$ of maize [45].

\section{Discussion}

We propose that EgCAD1, MdCAD1, QsCAD1, QrCAD1 and AtCAD3 belong to a group of proteins that diverged from the CADs involved in lignification and suberization. Like VR-ERE, they are probably enzymes whose up-regulation is induced in plant-pathogen compatible interactions with or without expression of disease symptoms. Initially, it was suggested, on the basis of the enzymatic activity of EgCAD1, that CAD1 could function as an alternative enzyme in the lignin biosynthetic pathway [32]. Thus, the possibility that the substrate for QsCAD1 is of host origin can not be entirely rejected. The elevated expression of the QsCAD1 could eventually be induced by compounds derived from aromatic polymers released through the action of degradative enzymes produced by the pathogen during infection. However, more recently, it was described [46] that plants down-regulated for CAD1 do not exhibit any changes in their lignin profiles but present significant modifications of their morphology and postulate that CAD1 could thus control a metabolic pathway involved in the production of aromatic substances playing a role in morphogenesis.

EgCAD1 [32] and VR-ERE [10] share a strong affinity towards a larger range of substrates than proteins grouped in cluster $\mathrm{A}$ and $\mathrm{B}$, converting benzaldehydes more efficiently than cinnamyl aldehyde derivatives. Nevertheless, these enzymes may also have developed specifically for processing certain substances like toxins, for which they should present a higher catalytic efficiency.

The high structural homology between QsCAD1, QrCAD1, EgCAD1 and VR-ERE, suggests that they have a common enzymatic activity and a similar function. The recombinant form of VR-ERE was shown to have the capacity to reduce aldehydic compounds, namely eutypine in eutypinol [10]. Eutypine, 4-hydroxy-3-(3-methyl-3-butene-1-ynyl) benzylaldehhyde is a toxin produced by $E$. lata, the causal agent of dieback of grapevines. The tolerance of some cultivars to this disease has been shown to be correlated with their capacity to convert eutypine into the corresponding alcohol, eutypinol, which lacks phytotoxicity. Previous studies have shown that eutypine plays an important role in the expression of the disease. It has been suggested [15] that during the growth period of grapevine, eutypine is transported from the trunk through the sap to the herbaceous parts of the vine where it induces a number of symptoms leading to the dead of the whole branch.

\footnotetext{
${ }^{4}$ GenBank accession nos.: AAA32783; CAA78930; CAA79154; CAA28734.
}

Dieback symptoms of grapevines resemble those exhibited by cork oak and holm oak suffering from $P$. cinnamomi infection. We propose that a mechanism similar to that involving eutypine in the dieback of grapevines caused by E. lata may apply to the sudden death of Quercus spp. involving $P$. cinnamomi. The occurrence of leaf chlorosis, wilting and death of branches, root necrosis, and sometimes tarry exudations on trunks, is followed by sudden death of crowns. Trees often die suddenly following one or two seasons of decline. These symptoms observed in the field suggest that, following infection, $P$. cinnamomi produces toxins that migrate through the sap from the roots to the leaves. Trees exhibiting sudden death symptoms are unable to detoxify these toxins. The homology between VR-ERE and QsCAD1, and our evidence for up-regulation of the gene in infected roots of cork oak seedlings, suggests a detoxifying role for the latter that may be inoperative in susceptible hosts, but partially or fully operative in hosts exhibiting chronic decline symptoms. The fragment C9 partially homologous to $Q S C A D 1$, isolated and identified exclusively from a cork oak tree with symptoms of sudden death, could derive from a gene coding for an inactive form of QsCAD1. The involved toxins should harbour a benzylaldehyde moiety, a common motive to substrates of VR-ERE. This is not the case of elicitins, polypeptides having toxic properties secreted by almost all Phytophthora species [47]. As a matter of fact no other toxins have been until now identified in Phytophthora species. Should, however these putative toxins be secreted by $P$. cinnamomi they could account for the remarkably wide host range exhibited by this species. We are presently identifying and investigating the phytotoxic nature of the substances detected in the culture medium of $P$. cinnamomi.

\section{Acknowledgements}

This work was financed by the EC-III Framework Programme for Research and Technological Development, co-financed by the European Social Fund (ESF) and by national funding from Ministério da Ciência e do Ensino Superior (MCES) (POCTI/AGR/34389/2000). Horta, M. thanks Fundação para a Ciência e a Tecnologia (FCT) and ESF (EC-III Framework Programme) for her Ph.D. Grant SFRH/BD/1249/2000. The authors are grateful to Professor C.M. Brasier for critically reading the manuscript.

\section{References}

[1] Brasier CM, Robredo F, Ferraz JFP. Evidence for Phytophthora cinnamomi involvement in iberian oak decline. Plant Pathol 1993; 42:140-5.

[2] Brasier CM. Phytophthora cinnamomi associated oak decline: environmental constraints including climate change. Ann Sci Forestières 1996;53:347-58.

[3] Moreira-Marcelino AC. Aspectos da interacção entre Phytophthora cinnamomi e a doença do declínio em Quercus suber e 
Quercus rotundifolia. $\mathrm{PhD}$ thesis. Faro, Portugal: University of Algarve, 2001.

[4] Sánchez ME, Caetano P, Ferraz J, Trapero A. Phytophthora disease of Quercus ilex in south-western Spain. Forest Pathol 2002;32:5-18.

[5] Meeley RB, Walton JD. Enzymatic detoxification of HC-toxin, the host selective cyclic peptide from Cochliobolus carborum. Plant Physiol 1991;97:1080-6.

[6] Zhang L, Birch RG. The gene for albicidin detoxification from Pantoea dispersa encodes an esterase and attenuates pathogenicity of Xanthomonas albilineans to sugarcane. Proc Natl Acad Sci USA 1997;94:9984-9.

[7] Zweillemuller M, Antus S, Kovacs T, Sonnenbichler J. Biotransformation of the fungal toxin fomannoxin by conifer cell cultures. Biol Chem 1997;378:915-21.

[8] Anzaï H, Yoneyama K, Yamaguchi I. Transgenic tobacco resistant to a bacterial disease by detoxification of a pathogenic toxin. Mol Genet Genom 1989;219:492-4.

[9] Meeley RB, Johal GS, Briggs S, Walton JD. A biochemical phenotype for a disease resistance gene of maize. Plant Cell 1992;4:71-7.

[10] Guillén P, Guis M, Martínez-Reina G, Colrat S, Dalmayrac S, Deswarte C, et al. A novel NADPH-dependent aldehyde reductase gene from Vigna radiata confers resistance to the grapevine fungal toxin eutypine. Plant J 1998;16:335-43.

[11] Mauro MC, Vaillant V, Tey-Rulh P, Mathieu Y, Fallot J. In vitro study of the relationship between Vitis vinifera and Eutypa lata. Demonstration of toxic compounds secreted by the fungus. Am J Enol Vitic 1988;39:200-4.

[12] Renaud JM, Tsoupras G, Tabacchi R. Biologically active natural acetylenic compounds from Eutypa lata. Helv Chim Acta 1989;72:929-32.

[13] Tey-Rulh P, Philippe I, Renaud J-M, Tsoupras G, Angelis P, Fallot J, et al. Eutypine, a phytotoxin produced by Eutypa lata the causal agent of dying-arm disease of grapevine. Phytochemistry 1991;30:471-3.

[14] Munkvold GP, Duthie JA, Marois JJ. Reductions in yield and vegetative growth of grapevines due to Eutypa dieback. Phytopathology 1994;8:186-92.

[15] Deswarte C, Canut H, Klaebe A, Roustan JP, Fallot J. Transport, cytoplasmic accumulation and mechanism of action of the toxin eutypine in Vitis vinifera cells. J Plant Physiol 1996;334:200-5.

[16] Colrat S, Latché A, Guis M, Pech J-C, Bouzayen M, Fallot J, et al. Purification and characterization of a NADPH-dependent aldehyde redutase from mung bean that detoxifies eutypine, a toxin from Eutypa lata. Plant Physiol 1999;119:621-6.

[17] Cadahia JM, Cobos JM, Soria S, Clauser F, Gellini R, Grossini P, et al. Observação de danos em espécies florestais mediterrâneas. Ministério da Agricultura, Pescas e Alimentação, Secretaria Geral Técnica e Comissão das Comunidades Europeias, 1991.

[18] Dudareva N, Cseke L, Blanc VM, Pichersky E. Evolution of floral scent in Clarkia: novel patterns of $S$-linalool synthase gene expression in the C. breweri flower. Plant Cell 1996;8:1137-48.

[19] Sambrook J, Russell D. Extraction, purification, and analysis of mRNA from eukaryotic cells. In: Molecular cloning: a laboratory manual. 3rd ed. New York: Cold Spring Harbor Laboratory Press; 2001.

[20] Money T, Reader S, Qu LJ, Dunford RP, Moore G. AFLP-based mRNA fingerprinting. Nucl Acids Res 1996;24:2616-7.

[21] Gubler U, Hoffmann BJ. A simple and very efficient method for generating cDNA libraries. Gene 1983;25:263-9.

[22] Gubler U. A one tube reaction for the synthesis of blunt-ended double stranded cDNA. Nucl Acids Res 1988;16:2726.

[23] Vos P, Hogers R, Bleeker M, Reijans M, van de Lee T, Hornes M, et al. AFLP: a new technique for DNA fingerprinting. Nucl Acids Res 1995;23:4407-14.

[24] Zabeau M, Vos P. Selective restriction fragment amplification: a general method for DNA fingerprinting. European Patent Application 924026297, Publication number 0534858A1, 1993.
[25] Bachem CWB, Oomen RJFJ, Visser RGF. Transcript imaging with cDNA-AFLP: a step-by-step protocol. Plant Mol Biol Rep 1998;16:157-73.

[26] Ribeiro OK. A source book of the genus Phytophthora. Vaduz, Liechtenstein: Cramer J.; 1978.

[27] Maruyama K, Sugano S. Oligo-capping: a simple method to replace the cap structure of eukaryotic mRNAs with oligoribonucleotides. Gene 1994;138:171-4.

[28] Volloch V, Schweitzer B, Rits S. Ligation-mediated amplification of RNA from murine erythroid cells reveals a novel class of beta-globin mRNA with an extended 5 -untranslated region. Nucl Acids Res 1994;22:2507-11.

[29] Thompson JD, Higgins DJ, Gibson TJ. CLUSTAL W: improving the sensitivity of progressive multiple sequence alignment through sequence weighting, position-specific gap penalties and weight matrix choice. Nucl Acids Res 1994;22:4673-80.

[30] Saitou N, Nei M. The neighbor-joining method: a new method for reconstruction phylogenetic trees. Mol Biol Evol 1987;4: 406-25.

[31] Altschul SF, Madden TL, Schäffer AA, Zhang J, Zhang Z, Miller W, et al. Gapped BLAST and PSI-BLAST: a new generation of protein database search programs. Nucl Acids Res 1997;25: 3389-402.

[32] Goffner D, Doorsselaere JV, Yahiaoui N, Samaj J, Grima-Pettenati J, Boudet AM. A novel aromatic alcohol dehydrogenase in higher plants: molecular cloning and expression. Plant Mol Biol 1998;36:755-65.

[33] Köhler Th, Lassner D, Rost A-K, Thamm B, Pustowoit B, Remke H. Quantitation of mRNA by polymerase chain reaction. Nonradioactive PCR methods. Springer laboratory manual. Berlin: Springer; 1995.

[34] Menke U, Mueller-Roeber B. RNA fingerprinting of specific plant cell types: adaptation to plants and optimization of RNA arbitrarily primed PCR (RAP-PCR). Plant Mol Biol Rep 2001;19:33-48.

[35] Baugh LR, Hill AA, Brown EL, Hunter CP. Quantitative analysis of mRNA amplification by in vitro transcription. Nucl Acids Res 2001;29:1-29.

[36] Coelho AC. Estudo da biodiversidade molecular de Quercus suber e caracterização de genes envolvidos na resposta de defesa à infecção por Phytophthora cinnamomi. Ph.D. thesis. Faro, Portugal: University of Algarve; 2004.

[37] Grima-Pettenati J, Feuillet C, Goffner D, Borderies G, Boudet AM. Molecular cloning and expression of a Eucalyptus gunnii cDNA clone encoding cinnamyl alcohol dehydrogenase. Plant Mol Biol 1993;21:1085-95.

[38] Lynch D, Lidgett A, Mclnnes R, Huxley H, Jones E, Mahoney N, et al. Isolation and characterisation of three cinnamyl alcohol dehydrogenase homologue cDNAs from perennial ryegrass (Lolium perenne L.). J Plant Physiol 2002;9:1037-43.

[39] Brill EM, Abrahams S, Hayes CM, Jenkins CLD, Watson JM. Molecular characterisation and expression of a wound-inducible cDNA encoding a novel cinnamyl-alcohol dehydrogenase enzyme in lucerne (Medicago sativa L.). Plant Mol Biol 1999;41:279-91.

[40] Anterola AM, Lewis NG. Trends in lignin modification: a comprehensive analysis of the effects of genetic manipulations/ mutations on lignification and vascular integrity. Phytochemistry 2002;61:221-94.

[41] Van Doorsselaere J, Baucher M, Feuillet C, Boudet AM, Van Montagu M, Inzé D. Isolation of cinnamyl alcohol dehydrogenase cDNAs from two important economic species: alfalfa and poplar. Demonstration of a high homology of the gene within angiosperms. Plant Physiol Biochem 1995;33:105-9.

[42] Logemann E, Reinold S, Somssich IE, Hahlbrock K. A novel type of pathogen defense-related cinnamyl alcohol dehydrogenase. Biol Chem 1997;378:909-13.

[43] Perham RN, Scrutton NS, Berry A. New enzymes for old: redesigning the coenzyme and substrate specificities of glutathione reductase. Bioessays 1991;13:515-25. 
[44] Iuchi S, Yamaguchi-Shinozaki K, Urao T, Terao T, Shinozaki K. Novel drought-inducible genes in the highly drought-tolerant Cowpea: cloning of cDNAs and analysis of the expression of the corresponding genes. Plant Cell Physiol 1996;37:1037-82.

[45] Johal GS, Briggs SP. Reductase activity encoded by the HM1 disease resistance gene in maize. Science 1992;258:985-7.
[46] Boudet A-M. Lignins and lignification: selected issues. Plant Physiol Biochem 2000;38:81-96.

[47] Pernollet J-C, Sallantin M, Sallé-Tourne M, Huet J-C. Elicitin isoforms from seven Phytophthora species: comparison of their physicochemical properties and toxicity to tobacco and other plant species. Physiol Mol Plant Pathol 1993;42:53-67. 